\title{
Kliničko istraživanje
}

KI01 Usporedba TNM klasifikacije i stadija karcinoma pluća u KBC-u Zagreb prije i za vrijeme pandemije

\author{
Marin Glavčića,b, Ivona Ćudina ${ }^{a}$, Pero Hrabača,c, Marijana Ćorića, \\ ${ }^{a}$ Medicinski fakultet, Sveučilišta u Zagrebu

 \\ c Škola narodnog zdravlja "Andrija Štampar" \\ ${ }^{\mathrm{d}}$ Klinički bolnički centar Zagreb
}

DOI: https://doi.org/10.26800/LV-143-supl3-KI01

Marin Glavčić (0000-0002-9065-4010), Ivona Ćudina (0000-0001-9640-4533), Pero Hrabač, Marijana Ćorić

Ključne riječi: Karcinom, Koronavirus, Pandemija, Pluća

UVOD:Zbog brzog širenja koronavirusa u Republici Hrvatskoj je 19. Ožujka 2020. godine proglašeno stanje pandemije tesusedoneseneslužbenemjerezasuzbijanješirenjavirusa.Kaoposljedicunavedenihmjeradošlojedosmanjenogopsega rada bolnicazbog preopterećenosti skoronavirus pozitivnim pacijentima te do smanjenog odlaska pacijenataubolnicuna nužne pretrage i liječenja zbog straha od zaraze koronavirusom. Cilj ovog istraživanja je bio kvantitativno i kvalitativno pokazati daliseikakomijenja udio pojedinih TNMklasifikacijai stadijakarcinomaplućaza vrijemepandemijeiprijeiste. MATERIJALI I METODE: Retrogradno smo prikupili i obradili ukupno 341 patohistoloških nalaza karcinoma pluća s potpuno određenom TNM klasifikacijom i stadijem tumora na Kliničkom zavodu za patologiju i citologiju KBC-a Zagreb. Za promatrani period pandemije smo uzeli vremenski raspon od 19. ožujka 2020. do 31. Prosinca 2020. godine dok smo za promatrano vrijeme prije pandemije uzeli isti taj vremenski raspon u 2019. godini. REZULTATI: Naši rezultati pokazuju da je tijekom pandemije COVID-19 došlo do statistički značajnog porasta udjela karcinoma s višim $\mathrm{T}$ kategorijama u promatranom vremenu pandemije u odnosu na isti period prošle godine $(\mathrm{P}=0.036)$. Kod $\mathrm{N}$ kategorije i stadija karcinoma pluća nisu pronađene statistički značajne razlike $(\mathrm{P}=0,280$; $\mathrm{P}=0,273)$.

ZAKLJUČAK: Ovo istraživanje pokazuje da je došlo do statistički značajnog porast postotka težih oblika karcinoma pluća u odnosu na ukupne karcinome pluća u periodu pandemije u odnosu na vrijeme prije početka pandemije. Potrebna su daljna istraživanja koja bi obuhvatila veći broj pacijenata u više bolnica kako bi dobili vjerodostojnije podatke na području cijele Republike Hrvatske.

\section{Comparison of TNM classification and stages of lung cancers in UHC Zagreb before and during the pan-} demic

Keywords: Cancer, Coronavirus, Lung, Pandemic

INTRODUCTION: Due to the rapid spread of coronavirus in the Republic of Croatia, a pandemic was declared on March 19, 2020, and official measures were taken to combat the spread of the virus. As a result of these measures, there was a reduced scope of work in hospitals due to overload with coronavirus positive patients and a decrease in the number of patients going to the hospital for necessary examinations and treatments due to the fear of coronavirus infection. The aim of this study was to show quantitatively and qualitatively whether there were changes of individual TNM classifications and stages of lung cancer during and before the pandemic.

MATERIALS AND METHODS: We retrogradely collected and processed a total of 341 pathohistological findings of lung cancer with a fully obtained TNM classification and tumor stage at the Clinical Department of Pathology and Cytology, University Hospital Center Zagreb. For the observed period of the pandemic, we took the time span from March 19, 2020 to December 31, 2020, while for the observed period before the pandemic, we took the same time span in 2019.

RESULTS: Our results show that during the COVID-19 pandemic there was a statistically significant increase in the proportion of cancers with higher $\mathrm{T}$ categories in the observed time of the pandemic compared to the same period last year $(\mathrm{P}=0.036)$. No statistically significant differences were found in $\mathrm{N}$ category and stage of lung cancer $(\mathrm{P}=$ $0.280 ; \mathrm{P}=0.273)$.

CONCLUSION: This study shows that there was a statistically significant increase in the percentage of more severe forms of lung cancer compared to total lung cancers in the pandemic period compared to the time before the onset of the pandemic. Further research is needed which could include a larger number of patients in more hospitals in order to obtain more reliable data throughout the Republic of Croatia. 